\title{
ISOLAMENTO DI NOCARDIA BRASILIENSIS IN UN CASO DI GRAVE INFEZIONE CUTANEA
}

\author{
'Bruno G., ${ }^{2}$ Frascaria P., ${ }^{2}$ Tomei A.R., ${ }^{2}$ Mariani M. \\ 'U.O. Medicina di Laboratorio e 2U.O. Malattie infettive \\ - Ospedale San Salvatore L'Aquila
}

Descriviamo un caso di cellulite superficiale in una donna di 66 immunocompetente, ricoverata in Malattie infettive. L'Ulcerazione cutanea si presentava in corrispondenza della gamba sinistra. La signora riferiva un trauma nella sede della lesione, una settimana prima, dovuto a un urto accidentale contro lo spigolo della scrivania di legno del suo ufficio. La progressione della lesione cutanea da papula a pustola fino all'ulcera era accompagnata da febbre continua, astenia, malessere generale. Gli esami di laboratorio documentavano leucocitosi (12.000 GB), neutrofilia (85\% neutrofili), $\mathrm{VES}=33 \mathrm{~mm}, \mathrm{PCR}=4,07 \mathrm{mg} \%$.Il pus prelevato dalla spremitura della lesione inoculato su brodo cuore- cervello dava assenza di crescita apparente dopo 48 ore di incubazione. Seminato direttamente sulle comuni piastre di agar a $37^{\circ} \mathrm{C}$, mostrava una decina di colonie bianche tenacemente adese all'agar sangue del diametro di appena $1 \mathrm{~mm}$.Al gram si presentavano come bastoncelli gram positivi ramificati. Data la nostra precedente esperienza di un caso di Nocardia asteroides isolato da escreato di una paziente con Sindrome di Kartagener,le cui colonie all'aspetto morfologico e tintoriale erano simili, spedivamo il ceppo al nostro referente del caso precedente (ora al Laboratorio di Microbiologia dell'Ospedale San Carlo Borromeo di Milano) .La risposta era questa volta di Nocardia brasiliensis.Il test di sensibilità dimostrava che il ceppo era sensibile a imipenem, gentamicina, amoxicillina -acido clavulanico, ceftriaxone, amikacina e trimetoprim- sulfametossazolo.La paziente veniva dimessa dopo 20 giorni di terapia con amikacina e cotrimossazolo con marcata guarigione della lesione. La terapia veniva completata dopo altri 70 giorni a domicilio di solo cotrimossazolo. Nocardia brasiliensis è stata descritta in Italia solo in pochi casi rispetto alla piu' comune $N$. asteroides. La nocardiosi è a nostro avviso sottostimata in Italia per la particolare crescita lenta delle nocardie le cui colonie, su agar sangue si sviluppano dopo almeno 2 giorni di incubazione. 